ANADOLU, J. of AARI

ISSN: $1300-0225$ (Print)

E-ISSN: 2667-6087 (Online)

2021, 31 (1): 126-135

DOI: $10.18615 /$ anadolu.950165

\title{
General Overview of Medicinal and Aromatic Plants in Turkey
}

\author{
Bekir PAKDEMIRL $\dot{I}^{*}$ (D) Nevzat BíRişí ${ }^{2}$ (D) Melek AKAY $Y^{3}$ \\ ${ }^{1}$ Republic of Turkey Ministry of Agriculture and Forestry, Ankara/ TURKEY \\ ${ }^{2,3}$ General Directorate of Agricultural Research and Policies (TAGEM), Ankara/ TURKEY \\ ${ }^{l}$ https://orcid.org/0000-0002-0336-0613 $\quad{ }^{2}$ https://orcid.org/0000-0002-2023-6155 \\ ${ }^{3}$ https://orcid.org/0000-0002-8717-0699 \\ *Corresponding author (Sorumlu yazar): bekir@pakdemirli.com \\ Received (Geliș tarihi): 15.03.2021Ａccepted (Kabul tarihi): 30.04.2021
}

\begin{abstract}
Medicinal and aromatic plants (MAPs) are widely used in traditional foods, as food supplements or herbal medicines throughout history. Recently, MAPs are generally defined as plants that are used as drugs to prevent or cure diseases in order to maintain health and for other purposes. In general, MAPs used as food, herbal tea, supplementary food and medicine are obtained from nature or through cultivation. There is a worldwide trend of increased use MAPs, and although treating diseases with medicinal plants is more common in Far East countries, the trade of herbal medicinal products is a rising market in western societies. When we consider the trend of MAPs, Turkey is an important genetic center of many plant species thanks to its geographical location and genetic diversity. In addition, Turkey is a main partner of many countries that demand MAPs products for the world MAPs market. In this paper, the current situation of MAPs production in the world and Turkey are reviewed based on available data. In addition, this review touches upon Turkey's historical, cultural and economic situation as well as the subsidies for and research and development $(R \& D)$ activities focused on MAPs. Finally, the opportunities, potential, problems and outlook in this area are described in order to inform future decisions about MAPs.
\end{abstract}

Keywords: Medicinal and aromatic plants, Turkey, agricultural economics.

\section{Türkiye'deki Tıbbi ve Aromatik Bitkilere Genel Bakıș}

ÖZ: Tıbbi ve aromatik bitkilerin (TAB'ler), geçmişten günümüze gıda takviyesi veya bitkisel ilaç olarak geleneksel gıda formlarında yaygin olarak kullanıldiğg bilinmektedir. Son zamanlarda ise TAB'ler genel olarak hastalıkları önlemek ve hastaların iyileşmeleri için ilaç ve başka amaçlar içinde kullanılan bitkiler olarak tanımlanmaktadır. Genel olarak gıda, bitki çayl, tamamlayıcı gıda ve ilaç olarak kullanılan TAB'ler doğadan toplama veya yetiştiricilik yoluyla elde edilir. Dünyada TAB'lerin kullanımında artan bir trend söz konusudur. Özellikle Uzakdoğu ülkelerinde tıbbi bitkiler hastalıkların tedavisinde daha yaygın kullanılırken bitkisel tıbbi ürün ticareti batı toplumlarında yükselen bir pazar haline gelmiştir. Türkiye ise gerek coğrafi konumu gerekse genetik çeşitliliği ile öne çıkan bir ülke olarak birçok bitki türünün önemli genetik merkezlerinden biridir. Ayrıca Türkiye, dünya TAB pazarında önemli bir role sahiptir. Bu çalışma ile var olan verilere çerçevesinde TAB'leri dünya ve Türkiye'deki mevcut durumu ele alınmıştır. Ayrıca, Türkiye'nin tarihsel, kültürel ve ekonomik durumu ile TAB'lere verilen desteklemeler ve bu alanda yapılan araştırma ve geliş̧irme (Ar-Ge) faaliyetlerine değinilmiştir. Bu çerçevede, tıbbi ve aromatik bitiklerin genel değerlendirmesi yapılarak geleceğe yönelik atılacak adımlar için TAB’ler alanlarındaki firsatlar, potansiyeller, sorunlar ve öngörüler incelenmiştir.

Anahtar kelimeler: Tibbi ve aromatik bitkiler, Türkiye, tarım ekonomisi. 


\section{INTRODUCTION}

Thousands of years ago, people recognized the therapeutic power of plants and took advantage of them to live healthily. Today, medicinal and aromatic plants (MAPs) are generally defined as plants that are used as drugs to prevent or cure diseases in order to maintain health and for other purposes. According to the World Health Organization (WHO) (Anonymous, 2015), an important portion of medical and pharmacological findings are completed through a greater understanding of natural plants, and the natural products collected from ecosystems are mostly accepted as reliable by many communities for medicinal and cultural purposes. Moreover, as WHO reports, a recent development is that approximately 4 billion people in the world first turn to herbal drugs to solve their health problems.

In history, approximately 250 plants were used as drugs during the Mesopotamian civilization period, while around 600 plants were used for medicinal purposes in the Ancient Greek period (Saber, 1982). Since the 1990s, the demand for natural products has increased, and the herbal-based medicine and cosmetics industry has developed rapidly (Anonim, 2017; Dar et al., 2017). As a result, the number of drugs known to be used in treatment and obtained from medicinal plants is greater than ever before. As Karık and Tunçtürk (2019) point out, the rate of drugs listed as originally made from plants is more than $40 \%$, although it was less than 5\% in the mid-1970s.

In general, while medicinal plants are used in fields such as sanitation, nutrition, cosmetics, body care and incense, aromatic plants are mostly used to give fragrance and taste. However, it is important to know that some plants are used for both medicinal and aromatic purposes. There are two types of MAPs: those collected from nature and those cultivated in the field. MAPs collected from nature spontaneously grow in places such as forests, pastures, and unused agricultural lands. Likewise, a significant proportion of MAPs traded worldwide is collected from nature.
MAPs have a wide area of use in both whole fresh and dry states. There are many different usage forms such as leaves, roots, flowers, seeds, shells, tubers or the entire aboveground part, fragmented or ground forms, and extracts prepared in different ways. Furthermore, the most common uses of MAPs in the food industry are as spices, herbal teas, food supplements and food additives. Some examples of common MAPs are black tea and coffee as well as sage, lime, mint, fennel, chamomile, rosehip, mountain tea, lemon balm, rosemary, thyme and anise which are all widely used in the category of herbal teas.

According to WHO data, approximately 20.000 plants are commonly used for medicinal purposes. The highest number of MAPs is found in China with 4.941 , followed by India with 3.000 , the USA with 2.564 , Vietnam with 1.800 , Malaysia with 1.200 and Indonesia with 1.000 , while the number of MAPs in Turkey is 500 (Schippmann et al., 2002). On the other hand, the main trade centers for herbal drugs in the world are China, Germany, the USA, France, Italy, Japan, Spain, England and Hong Kong (Faydaoğlu and Sürücüoğlu, 2011). It is difficult to determine the world production and trade figures, as there is no system that specifically classifies MAPs.

The current situation seems to be that data of each MAP is not accurately provided by any national or international database system in many countries. As a result, this paper first covers the current situation based on available data of MAPs in the world. In the second part, the historical, cultural and economic situation of Turkey's MAPs and the government's role in subsidies and research and development (R\&D) activities will be touched upon. Then, the opportunities, potential, problems and outlook of MAPs will be given to guide future decisions. The final conclusion will be based on the general overview of MAPs in Turkey.

\section{MAPs in the World}

The distribution of plants on Earth is uneven, but the tropics are the richest areas of diversity, 
especially the northern parts of South America and the Indonesian archipelago (Anonim, 2016). The number of plant species in the world is estimated as 320.000 with 3.000 of them used just for food production, 25.000 for treatment, 5.000 for industrial purposes, 15.000 as ornamental plants, and the rest are applied for other purposes (Karı and Tunçtürk, 2019). Moreover, the number of medicinal plants popular worldwide is $4-6.000$, and the number of species traded is 3.000 (Acrbuca and Budak, 2018).

Especially after the 1990s, the use of medicinal and aromatic plants is increasing daily with the discovery of new areas of use as well as increased demand for natural products (Temel et al., 2018). When we look at the production of MAPs in the world, China and India are the biggest producers of medicinal plants which are mostly collected from nature. Schippmann et al. (2002), claim that while 800 plants in China are collected from nature, 1.000 commonly used medicinal plants are collected from nature in India. On the other hand, in Europe, the total number of species traded is around 2.000 and approximately $60 \%$ of them are collected from nature. Bulgaria has the highest rate of gathering MAPs from nature with 750 plants, followed by Romania with 350 species. The number of species cultivated throughout Europe and commonly used is about 140 and remains at a very low level (Schippmann et al., 2002).

When we look at the MAP production areas in the world in 2018 (Table 1), coffee production has the largest area with 10.5 million hectares (ha). Brazil, Indonesia, Colombia and Ethiopia account for approximately $43 \%$ of the total coffee production area. Tea has the second highest production area, and China, India and Kenya have $76.3 \%$ of the world's total tea areas. In addition, Turkey has 84 thousand ha of tea production and ranks 8th in the world. Anise, fennel and coriander are also cultivated in large areas with 1.2 million ha worldwide. India (71.6\%), Syria and Turkey (4.4\%) have the most total anise, fennel and coriander production areas.
In 2018 , India produced $67.8 \%$ of the world's total spice with 1.9 million tons in the world. It is well known that India uses many kinds of spices as they have such colorful cultural and consumption habits. Turkey produced 246 thousand tons $(8.7 \%)$ of spices in the same period. Piper-type peppers (black pepper, etc.) represent a large proportion of total spice production and are produced on 586 thousand ha worldwide. Indonesia, India and Vietnam represent $73 \%$ of the total production areas. Other medicinal and aromatic plants produced in the world are shown in Table 1. Ginger is produced on 373 thousand ha, India ranks first in ginger with an area of 168 thousand ha, followed by Nigeria with 72 thousand ha and China with 47 thousand ha. As a result, approximately $64 \%$ of ginger production is carried out by India (32.0\%), Nigeria (18.3\%) and China $(13.2 \%)$. Other important MAPs in the world include cumin, thyme, sage, sumac, juniper, rosemary, bay, thistle, basil, linden, nettle, saffron, milk thistle, licorice, and caraway (Keykubat, 2016; Dar et al., 2017).

In world trade, MAPs are divided into six main product groups in the harmonized system. These product groups are 07 (edible vegetables, some roots and tubers), 09 (coffee, tea, mate and spice), 13 (seeds and plant parts), 3301 (lac, gum, resin, etc.), and 12 (essential oils, etc.). According to available data, the world trade of MAPs has increased since 2001. The export value, which was 18.3 billion USD in 2001, reached 70.7 billion USD in 2019. The most important main product group subject to world exports is coffee, tea, Paraguay tea and spices with a $66.9 \%$ share in total exports. Among the products in this group, coffee and coffee pods constitute the highest share with $62.4 \%$ of the world total MAP trade. A total of 29.8 billion USD of coffee and coffee pods were exported in 2019; Brazil (4.6 billion), Switzerland ( 2.5 billion) and Vietnam (2.5 billion) are the main exporters (Anonymous, 2021b).

On the other hand, in the sub-group of ginger, saffron, thyme, laurel, etc., China, India and the Netherlands are among the main exporting 


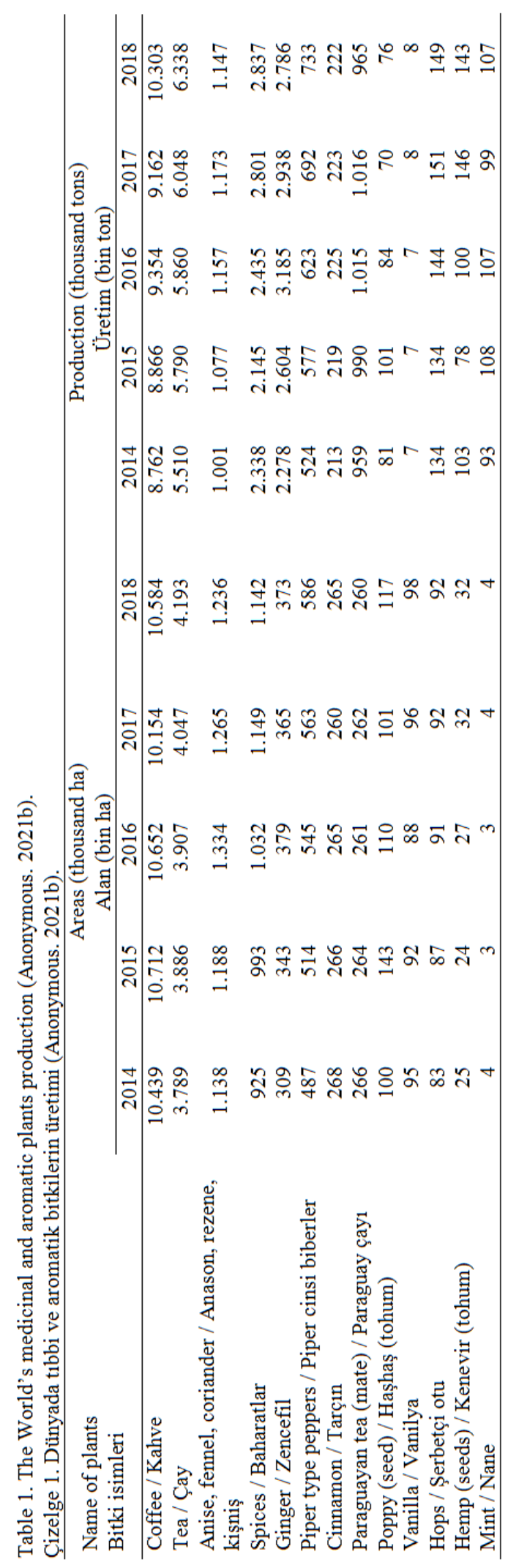


countries. Ginger is one of the most important exported spices in this group, with a value approaching 890 million USD. The other important suppliers of this product, for which China has the largest export value, are the Netherlands and Thailand. Other important spices and their main exporters are cumin from India and Syria, vanilla from Madagascar and France, cinnamon from Sri Lanka and China, saffron from Iran and Spain, and turmeric from India (Anonymous, 2021a).

In the world MAP export market, the export share of countries such as European countries and the USA have high values as they mostly use MAPs for raw materials in the food, beverage and perfumery industries and in other processed products. On the contrary, spices, coffee and tea products are mostly used by China, India, South American countries, Vietnam, Kenya, Indonesia and Turkey (Anonim, 2018).

\section{MAPs in Turkey}

Turkey has a great advantage in terms of its geographical position, climate, plant diversity, agricultural potential and a large surface area to produce MAPs. In addition, it is one of the leading countries in the trade of MAPs to the EU. Turkey is located at the intersection of three phytogeographical regions, and is a bridge between Southern Europe and Southwest Asian MAP flora. These MAPs are used as inputs for the herbal medicine, plant chemical, food and additives, cosmetics and perfumery industries.

Plant diversity in Turkey paves a way to understand the importance of MAPs in terms of history and culture. Turkey is surrounded on three sides by the sea and has different microclimate features such as steppe, forest, maquis, rocky and salty regions. The plant richness of Turkey stems from these different geological and topographical features and from its location at the intersection of three regions. In its historical development, Anatolia was located on migration routes and has hosted many civilizations, which play an important role in increasing plant diversity and enrichment of gene resources. Anatolia is also the gene center of many cultivated plants in the world. Nowadays, although the number of MAPs is not exactly known in Turkey, it is estimated to be around 500, 200 of which have great export potential (Baytop, 1999; Faydaoğlu and Sürücüoğlu, 2011).

MAPs are basically gathered from nature and cultivated in fields based on the organic and good agricultural farming system in Turkey. According to the General Directorate of Forestry (OGM), laurel ranks first within the scope of non-wood products from forest areas with 32.5 thousand tons. Moreover, chestnut is in second place with 5.9 thousand tons, and thyme is in third place with 1.8 thousand tons. There are many MAPs such as carob, myrtle, moss, rosin, rosemary, sage, summer snowflake, cistus, rosehip, and linden blossom that are directly collected from nature (Anonim, 2020b). For example, it is important to highlight that while $99.6 \%$ of organic thyme is produced in Antalya, $62.7 \%$ of the thyme collected from nature is gathered from the Aegean region, especially in Izmir.

Considering the usage of MAPs, it is evident that products obtained with organic farming and good agricultural practices are frequently preferred by consumers. A total of 44 thousand tons of MAPs were produced in a total area of about 18 thousand ha within the scope of organic agriculture in 2019 (Anonim, 2020a). The amount of MAPs produced with good agricultural practices was 32 thousand tons in 2019, with cumin, thyme and black cumin as the most produced MAPs.

As an example, thyme is a plant that has many uses, especially in the spice, pharmaceutical, cosmetic and chemical sectors. The demand for thyme has increased thanks to alternative medicine applications, and it has become a product with increasing economic value. While some of the thyme is collected from nature, recently some types of thyme have been cultivated on agricultural land in order to meet the demand for export.

MAP production is mostly carried out by small family businesses, and having small fields is a problem that makes mechanization unmanageable. 
Therefore, it seems that MAPs are produced by manual labour. When we look at the MAPs' production cost, sesame, anise, hops, cumin and thyme have the highest costs, with labour costs generally having the highest share in total costs.

\section{Main MAPs production}

The MAP production areas increased by $91.7 \%$ in 2019 compared to 20 years ago. Turkey had 167.2 thousand ha in 2019. Table 2 shows the production areas and amount of MAPs in Turkey with respect to the last five-year period based on Turkish Statistical Institute data.

When we look at the MAP production area, poppy production has the largest area in Turkey. Poppy production, import and export are regulated by the Protocol of the United Nations with Single Convention on Narcotic Drugs. Legally, France, Spain, Hungary, Australia, India, Turkey and China are allowed to produce poppy. Turkey produced 27.3 thousand tons of poppy cultivated in 677 thousand ha in 2019. With regard to poppy production areas by province, Afyonkarahisar has the largest area with $23.7 \%$ of the total, followed by Denizli with $18.9 \%$ and Konya with $5.3 \%$. While Afyonkarahisar ranks first in total poppy production with 7.6 thousand tons, Konya, which is in the third place in production area, is in the second place for production with 5.6 thousand tons due to high yield. There are many breeding studies in Turkey focused on poppy production to increase its industrial potential and its place in the world market.

Cumin production, which has the highest share after poppy production in terms of total area, increased approximately 2.5 times in 2019 compared to 20 years ago and was produced on 32 thousand ha. The total cumin production in 2019 was 20.2 thousand tons, with $80.4 \%$ of cumin production in Ankara (41.5\%) and Konya (38.3\%). On the other hand, anise production had an increase of $92.2 \%$ in 2019 compared to the previous year. In anise production, Konya takes first place with 5.3 thousand tons of production, while Burdur is second with 3.5 thousand tons and Denizli is third with 2.2 thousand tons of production.

Although a significant proportion of thyme was collected from nature in the past years, more recently it has been cultivated in large agricultural areas. As a result, the majority of exported thyme has been produced as a cultivated plant. Thyme production areas increased 3.3 times in 2019 compared to 2005 and reached 15.7 thousand ha. Denizli, which is the most important province in thyme production, had $92.5 \%$ of the total thyme cultivation area in 2019 and met 15.7 thousand tons $(87.6 \%)$ of total production.

As MAPs, rose, thyme, lavender, anise, fennel and sage are important species used in essential oil production, and particularly thyme, lavender and sage use has increased over the years in Turkey (Karık and Öztürk, 2010). Recently, some new herbs such as rosemary, echinacea, caper, licorice, stevia, chamomile, gypsophila, tarragon and basil are among those that are cultivated (Anonim, 2018). For instance, having a high potential for exporting roses, Turkey needs to increase the added value of the products instead of exporting raw materials. With regard to this, Turkey will increase its rose oil export revenues.

The government supports of MAP production in the current situation have an important role in increasing the quality and quantity of MAPs and to meet demand at the national and international levels. The supports for MAP production are given under the title: Diesel-Fertilizer, Organic Agriculture, Good Agricultural Practices, Domestic Certified Sapling/Seedling and Standard Sapling Use, Small Family Business, Young Farmer, Rural Development, Renting of Public Land, and finally Agricultural Loan Interest subsidies. 


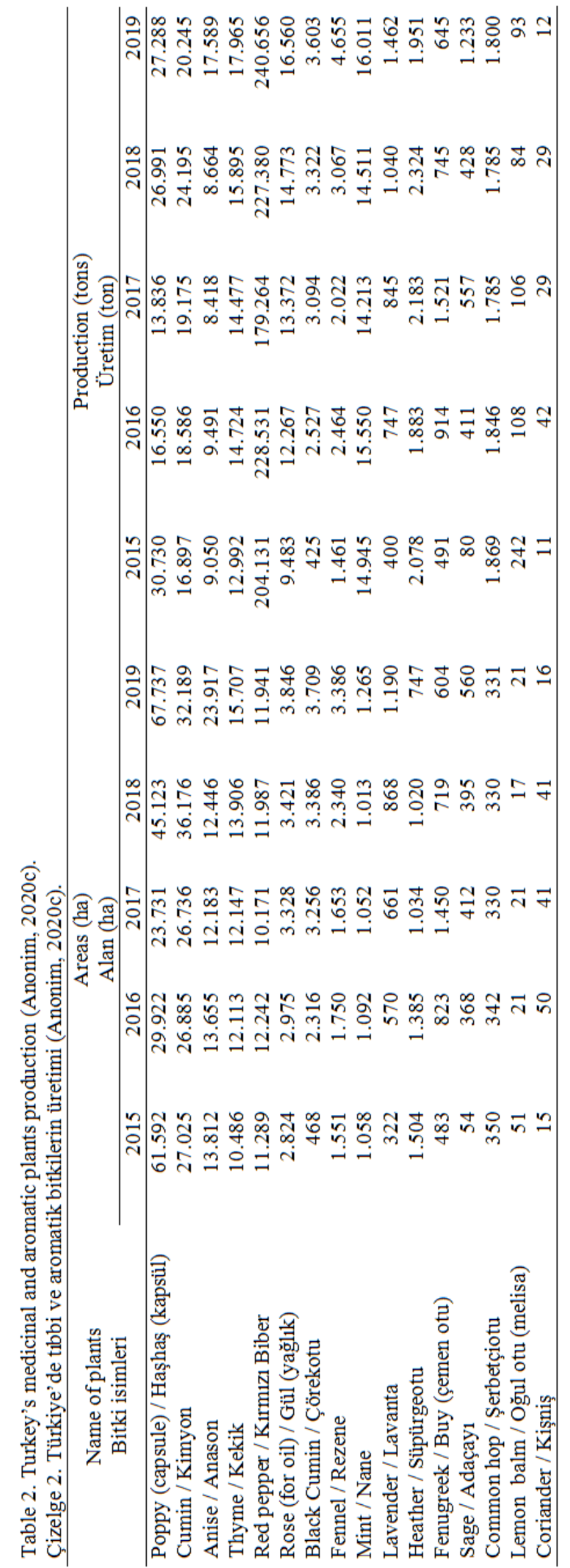


In recent years, Research and Development (R\&D) activities for MAPs have been enlarged throughout Turkey with the collaboration of universities, public and private sectors. Significant studies have been conducted in breeding and the number of registered varieties has increased together with the intense interest and demand for MAPs. Consequently, MAP R\&D projects have been ongoing in the fields of cultivation, breeding and variety development. For instance, registration studies have been initiated for plants such as flax, anise, coriander, thyme, sage, basil, lemon balm, echinacea, black cumin, saffron, mountain tea, blessed thistle (cnicus), nettle and hemp in recent years. To date, 80 species have been registered in Turkey, and 33 varieties in 16 species have been registered by General Directorate of Agricultural Research and Policies (TAGEM) institutes, 29 varieties in seven species by the private sector, eight varieties in four species by universities, and other public institutions have just registered 10 poppy cultivars (Anonim, 2020d). Moreover, there is $R \& D$ on herbal teas and oils acquired from MAPs, particularly for health effects.

\section{Main MAPs trade}

With respect to the trade data for the main MAPs in Turkey obtained from TUIK, Turkey increased its MAP export value 3.5 fold with approximately 371 million USD in 2019, as compared to 106 million USD in 2001. Considering Turkey's total MAPs export value, coffee, tea, Paraguayan tea and spices are recorded in the main product groups with the highest share, $63 \%$. The main export product group also includes ginger, saffron, thyme and laurel. The export values of thyme and laurel (also called bay leaf) are about 54 million USD and 38 million USD, respectively. In world thyme and laurel export, Turkey is one of the largest exporters (Anonim, 2020c). Turkey's thyme export volume and value surged by $31 \%$ and $92 \%$, respectively from 2010 to 2019 with the main importers being the Aegean Free Zone, the US and Germany. On the other hand, Turkey exported around 14 thousand tons of laurel in 2019, and more than half of it was exported to Vietnam, China and the US.
The export value of essential oils was 49 million USD consisting of approximately 13 million USD from rose oil, 12 million USD from citrus and other non-mint oils, 1.1 million USD from stearoptene, and 3.9 million USD thyme oil in 2019. France, England, Switzerland and the US are the main importer of Turkey's essential oils. In addition, the product group of anise, fennel, coriander, cumin and similar spices is an important group with an export value of 22.4 million USD. The products with the highest export value in this group are cumin and anise. Last but not least, tea, which is in the main product group of coffee, tea, Paraguayan tea and spices, is an important product with an export value of 15.1 million USD and is mostly exported to Belgium and Germany.

MAP imports have increased in recent years and reached 656.5 million USD in 2019. Sesame seed is the product with the highest import value in the MAP sub-product groups with 267.4 million USD corresponding to 170.6 thousand tons, with $46.8 \%$ of sesame seeds imported from Nigeria in the same year. The other imported MAPs are coffee and its products with $70.4 \%$ of imports from Brazil; tea with almost $80 \%$ of imports from Sri Lanka; thyme with $68.9 \%$ of imports from Albania and Mexico; and essential oil which is mostly imported from Indonesia and France.

Considering the foreign trade balance of MAPs, the sesame seed trade deficit was 233.8 million USD, and coffee and coffee products had a deficit of 181.4 million USD in Turkey in 2019. The most important groups with foreign trade surplus are ginger, saffron, thyme, laurel and similar products with 92.3 million USD, and poppy seed with 90.3 million USD (Anonim, 2018).

Although Turkey is very rich in natural resources, it continues to be an exporter of unprocessed raw plants and imports many MAPs. Unfortunately, while it is possible to increase the economic returns of many MAPs produced and traded in Turkey such as cumin, saffron, thyme, black cumin, sage, lime, garlic, and coriander to higher levels, recent global developments in raising standards have worked against Turkey. In this 
manner, in order to have a consistent place in world trade, Turkey needs to follow the world trend in MAPs production while planning the trade and production of MAPs.

\section{RESULTS and DISCUSSION}

A significant portion of MAPs is collected from nature, and this causes difficulties in continuously meeting the raw material needs of the sector. There is also a risk due to the unconscious collection of MAPs. As a result, the MAPs collected from nature must be protected to ensure the long-term existence and genetic diversity of these species.

The production of medicinal and aromatic plants is a labor-intensive branch of production. Considering the labour costs, machinery and equipment used on a small farm scale can be developed in order to reduce the cost. On the other hand, it is a fact that the MAP products providing added value have not yet been defined in the marketing system of MAPs. Hence, there is insufficient awareness of the uses and forms of MAPs, especially the products with health risks.

Capacity and technology in the MAP sector must be evaluated at the local level in Turkey. Given an example from the essential oil sector, there are problems in the use of capacity. While there is periodic idle capacity in the sector during the year in some regions, the capacity is not sufficient in other regions. For this reason, it is necessary to ensure clustering of product or product groups on a geographical basis.

In addition to the development of high capacity MAP production, there is a need to increase the quality of products demanded by the national and international markets. The most important factor affecting quality is the selection of varieties based on suitable ecology and market demands. Moreover, improvements are required in breeding, harvesting, storage, processing and marketing. Besides breeding, post-harvest practices significantly affect the quality. MAPs, which are largely dried and stored after harvest, should be examined for contamination during the drying process.

\section{CONCLUSION}

Turkey has a wide variety of plant species due to its geographical location and climate characteristics. Considering Turkey's soil and water resources and the current state of biodiversity, it is important to increase the country's global competitive power in order to ensure the production of MAPs with the quality and characteristics demanded by the markets for these products. In addition, it is essential to turn Turkey's biodiversity into an advantage in international markets. In other words, such biodiversity can be evaluated in an economic and environmental framework. Considering the importance of MAPs in Turkey's economy, the sector needs to remedy its shortcomings in order to increase the share of Turkey's role in the world MAPs trade market.

In terms of a marketing strategy, a goal can be to enhance the market facilities of MAP production at the domestic and worldwide level and to create additional added value. In line with this goal, information sharing might be achieved by bringing together actors such as farmers, collectors, intermediaries, processors, wholesalers, retailers, exporters, importers and consumers on transparent platforms in order to supply the right product to the market in a competitive manner. Moreover, consumers are the most dynamic and crucial factor in marketing strategy so it is essential to analyse market needs based on the production and processing of MAPs.

From the perspective of producers and processors, contractual agriculture needs to be expanded for a sustainable farmer-dealer relationship. In order to ensure continuity in production and product standards, conditions must be established to create a purchase guarantee of a certain amount of product in contracted production.

Turkey is aware of its MAPs production potential, it is, therefore, important to analyse the competitor countries in the sector and to find new markets. In addition, measures should be taken to protect national market products such as poppy, thyme and 
laurel that have an important place in the world market. When we look at the world trend, developed countries like the USA and EU countries increase their quality criteria day by day. As Turkey also has an increasing trend in MAP production, the sector should develop production processes and add more value by creating product varieties of MAPs in accordance with world criteria.

\section{REFERENCES}

Acıbuca, V. ve D. Bostan Budak. 2018. Dünyada ve Türkiye'de tıbbi ve aromatik bitkilerin yeri ve önemi. Çukurova Tarım Gıda Bil. Der. 33(1): 37-44.

Anonim. 2016. Tibbi aromatik bitkiler ve iyi yaşam. İzmir Ticaret Borsas1. http://itb.org.tr/dosya/rapordosya/ tibbi-aromatik-bitkiler-ve-iyi-yasam.pdf? $\mathrm{v}=$ 1506816000032

Anonim. 2017. Tibbi ve Aromatik Bitkiler AR-GE Projesi Eğitim Kitabı. https://www.kalkinmakutuphanesi. gov.tr/dokuman/tibbi-ve-aromatik-bitkiler-ar-geprojesi-egitim-kitabi/1637

Anonim. 2018. T.C. Tarım ve Orman Bakanlığı, Bitkisel Üretim Genel Müdürlüğü Tıbbi ve Aromatik Bitkiler Ulusal Eylem Planı. Basılmamış yayın. Ankara

Anonim. 2020a. T.C. Tarım ve Orman Bakanlığı, Bitkisel Üretim Genel Müdürlüğü verileri. Ankara.

Anonim. 2020b. T.C. Tarım ve Orman Bakanlı̆̆1, Orman Genel Müdürlüğü. Odundışı Orman Ürünleri Daire Başkanlığı istatistikleri kayıtları. Ankara.

Anonim. 2020c. Türkiye İstatistik Kurumu (TUIK) https://data.tuik.gov.tr/Kategori/GetKategori?p=DisTicaret-104.

Anonim. 2020d. T.C. Tarım ve Orman Bakanlığı, Tohumluk Tescil ve Sertifikasyon Merkez Müdürlüğü. https:// www.tarimorman.gov.tr/BUGEM/TTSM/Sayfalar/Det ay.aspx?SayfaId $=136$

Anonymous. 2015. https://www.who.int/news-room/factsheets/detail/biodiversity-and-health

Anonymous. 2021a. The International Trade Centre (ITC). https://www.trademap.org/Index.aspx.
The targeted level in foreign markets can be achieved when MAP product varieties are increased and meet the appropriate standards and quality parameters. Since MAPs products are not only used and commercialised for medicinal purposes but also for herbal extract, essential oil and concentrates, the value of these products can increase rapidly in an economic and strategic manner.

Anonymous. 2021b. The Food and Agriculture Organization (FAO). http://www.fao.org/faostat/en/\#data/QC

Baytop, T. 1999. Türkiye'de Bitkiler ile Tedavi, Geçmiste ve Bugün. Nobel Tıp Kitabevleri. II. Baskı ISBN: 975420-021- Istanbul.

Dar, R. A., M. Shahnawaz, and H. Qazi. 2017. General overview of medicinal plants: A review. The Journal of Phytopharmacology 6(6): 349-351.

Faydaoğlu E. ve M.S. Sürücüoğlu. 2011. Geçmişten günümüze tıbbi ve aromatik bitkilerin kullanılması ve ekonomik önemi. Kastamonu Üniversitesi Orman Fakültesi Dergisi 11(1):52-67.

Karık, Ü. ve M. Öztürk. 2010. Uçucu yağ sektörünün ulusal ekonomimizdeki yeri, sorunları ve çözüm önerileri. Alatarım 9(2): 30-37.

Karık, Ü., and M. Tunçtürk. 2019. Production, trade and future perspective of medicinal and aromatic plants in Turkey. Anadolu J. of AARI 29(2):154-163.

Keykubat, B., 2016. Medicinal and aromatic plants and good life. Izmir Commodity Exchange R\&D Department.

Saber, A.H. 1982. Chronological notes on medicinal plants. Hamdard 25(1-4):57.

Schippmann, U., D. J. Leaman, and A. B. Cunningham. 2002. Impact of cultivation and gathering of medicinal plants on biodiversity: Global Trends and Issues. p. 12-13. October 2002. Inter-Departmental Working Group on Biological Diversity for Food and Agriculture. Roma.

Temel, M., B. Tinmaz, M. Öztürk, ve O. Gündüz. 2018. Dünyada ve Türkiye'de tıbbi-aromatik bitkilerin üretimi ve ticareti. KSÜ Tarım ve Doğa Derg. 21(Özel Say1): 198-214. 